\title{
Advanced Gastric Small Cell Carcinoma
}

National Cancer Institute

\section{Source}

National Cancer Institute. Advanced Gastric Small Cell Carcinoma. NCI Thesaurus. Code C156685.

A gastric small cell carcinoma that has spread extensively to other anatomic sites or is no longer responding to treatment. 